\title{
THE BRAZILIAN BIODIESEL PROGRAM AND FAMILY FARMERS: WHAT IS THE SOCIAL INCLUSION REALITY IN THE BRAZILIAN SAVANNAH? ${ }^{1}$
}

\author{
Marcus Vinicius Alves Finco², Werner Doppler ${ }^{3}$
}

\section{RESUMO \\ O PROGRAMA BRASILEIRO DE BIODIESEL E OS AGRICULTORES FAMILIARES: QUAL É A REALIDADE DA INCLUSÃO SOCIAL NO CERRADO?}

A produção de biocombustíveis tem sido fortemente discutida no Brasil, levando o País a desenvolver políticas e implementar, no ano de 2004, o Programa Nacional de Produção e Uso de Biodiesel (PNPB), a fim de aumentar a participação de energias renováveis, bem como fomentar o desenvolvimento rural. Neste contexto, o presente estudo busca avaliar a relação entre a condição de vida dos agricultores e a adoção do cultivo de oleaginosas no Estado do Tocantins, em uma região de transição entre o Cerrado e a Floresta Amazônica. Uma gama de indicadores socioeconômicos foram coletados entre os agricultores que cultivam pinhão manso e mamona. Análise fatorial baseada na condição de vida dos agricultores e um modelo não-linear probit foram utilizados para avaliar a inclusão de famílias rurais pobres na cadeia do biodiesel. Os resultados preliminares mostram uma relação positiva entre o nível de privação da família e a adoção do cultivo de oleaginosas, no caso da produção de Ricinus communis, e uma relação negativa, no caso da produção de Jatropha curcas.

PALAVRAS-CHAVE: Programa Brasileiro de Biodiesel; agricultores familiares; inclusão social; Cerrado.

\section{INTRODUCTION}

Global concern for the depredation and exhaustion of natural resources has led governments and scientists around the world to identify alternatives and solutions to the problem. Since the beginning of the $21^{\text {st }}$ Century, an international debate has taken shape, which is currently discussed at 10 out of 10 meetings on sustainable development around the world: biofuels pros and cons (Dubois 2008, FAO 2008a, FAO 2008c). From a socio-economic point of view, biofuels ${ }^{1}$ can positively impact rural

${ }^{1}$ Biofuel essentially refers to liquid fuels derived from agricultural crops, used for transport and energy generation (FAO 2008b).

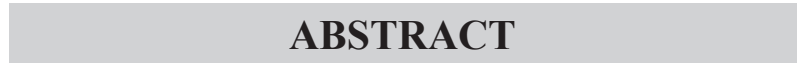

Biofuel production has been greatly discussed in Brazil. In 2004, some debates led the country to develop new policies and implement the National Biodiesel Use and Production Program (PNPB), with the intent to increase the share of renewable energy and foster rural development. In this context, the present study aims to assess the linkages between family farmers living standard and the adoption of oil seed activity in the Tocantins State, in a region of transition between the Cerrado (Brazilian savannah) and the Amazon rain forest. Ranges of socio-economic indicators were collected among smallholders who cultivate Jatropha curcas and Ricinus communis. A factor analysis based on living standard criteria and a non-linear probit model were applied to assess the inclusion of poor rural families in the biodiesel chain. Preliminary results point towards a positive relation between the family degree of deprivation and adoption of oil seed activity, for the Ricinus communis production, and a negative relation, for the Jatropha curcas production.

KEY-WORDS: Brazilian biodiesel program; family farmers; social inclusion; Cerrado.

development and diversify the utilization of the local environment, for example, enhancing rural space multi-functionality, where farms are used not only for crop production, but also for eco and rural tourism, and, of course, generating strategies that reduce and alleviate poverty, the so-called 'pro-poor' strategies (UN Energy 2007, FAO 2008b).

Based on that, in 2004, the Brazilian government launched a national biodiesel program PNPB (Brasil 2005), which was designed based on a scenario of high oil prices, a growing demand for fuels from renewable sources, and the country's comparative advantage in natural resources (Nass

1. Trabalho recebido em jun./2010 e aceito para publicação em nov./2010 (nº registro: PAT 10096/ DOI: 10.5216/pat.v40i4.10096).

2. Universidade Federal do Tocantins, Departamento de Administração, Palmas, TO, Brazil.

E-mail: marcus.finco@gmail.com.

3. University of Hohenheim, Institute of Agricultural Economics, Stuttgart, Germany. E-mail: doppler@uni-hohenheim.de. 
et al. 2007). The PNPB is an interdepartmental program of the Brazilian government, with goals such as implementing the production and use of biodiesel, while focusing on social inclusion and regional development ${ }^{2}$. Moreover, the PNPB has several specific objectives: i) implement a sustainable program, promoting social inclusion; ii) guarantee competitive prices, quality and supply; and iii) produce biodiesel from different vegetable oil species $^{3}$.

Five years after the PNPB implementation, data released by the National Oil, Natural Gas and Biofuels Agency (ANP) demonstrated that biodiesel, in Brazil, at the macro level, is being produced mainly from soybean and animal fat (roughly $80 \%$ and $15 \%$, respectively), which are, in most cases, produced by large-scale farmers (ANP 2010). The PNPB impacts, at a micro level, however, are uncertain, especially regarding the effectiveness of implementing social inclusion, i.e. there is uncertainty about whether poor rural families are being included in the national biodiesel chain. Social inclusion is a process that aims to offer opportunities to access goods and services to the most excluded people within a system and, therefore, benefit all and not only those in better off conditions (Pierson 2002, Silver \& Miller 2002) [Emphasis added].

The impact on farmers will be contingent on a range of factors like the market structure, type of contracts, and protection against risks, for instance. This is another area that has not been addressed in the current literature (Rajagopal \& Zilberman 2007). In this context, the present study aims to analyze the relationship and linkages between poor rural families and the adoption of small-scale oil seed production, from two different farming systems, in northern Brazil, therefore assessing whether the PNPB's 'pro-poor' strategy is effective or not. The research will support the regional and national governments in improving the PNPB and social inclusion targets. Moreover,

\footnotetext{
${ }^{2}$ According to Abramoway \& Magalhães (2007) and Garcez \& Vianna (2009), the biodiesel policy has the clear objective of promoting the social inclusion of family farming. This is a very commendable and much needed proposition, specifically in Brazil, a country that has one of the worst land distribution rates in the American continent and great disparities between the wealth of large, industrial-scale farming versus family-based counterparts.

${ }^{3}$ The PNPB has also a differential to other biodiesel programs created during the 1980 s, in Brazil, such as the national vegetable oils program to energy production (Pró-Óleo) and the vegetable oils program (OVEG). Apart from the production and use of biodiesel in the country, the PNPB focuses mainly on social inclusion and also takes into account the environmental aspects of biodiesel production. Due to the importance of the social inclusion target, the national government established a range of different instruments aiming at fulfilling this target, such as fiscal exemptions, financial subsidies, and specific credit lines to biodiesel companies.
}

the results presented can play an important role in integrating efforts to consolidate a new economic alternative for the small-scale farmers in the country.

\section{MATERIAL AND METHODS}

The research was carried out in the Tocantins State, located in northern Brazil, a region known as the Brazilian Legal Amazon. The State is situated in a transition area, containing climate and vegetation patterns from both the Amazon rain forest (15\% of the territory) and the Cerrado ( $85 \%$ of the territory). This transition area, so-called Ecotone zone, is home to traditional communities (family farmers and indigenous, as well as quilombolas ${ }^{4}$ ) and comprises rich biodiversity, which is responsible for numerous environmental services. For this reason, scientific studies and research in the area are extremely important, since they are often focused on understanding the different farming systems, their connections to the local economy, and the very diverse environment. Based on that, and in order to obtain the appropriate information, a macro study region was selected, in the south-west part of the Tocantins State (Figure 1).

In addition, two sub-study regions were selected within the macro study region. Each substudy region comprises smallholders who produce certain type of oil seed, as well as have contracts with one of the biodiesel companies established in the State. Therefore, the two sub-study regions have been defined and focused on the different types of vegetable oil species. So, the sub-study regions are:

1. Jatropha curcas sub-study region: comprised by an area from the city of Paraíso do Tocantins up to the city of Caseara, both situated in western Tocantins.

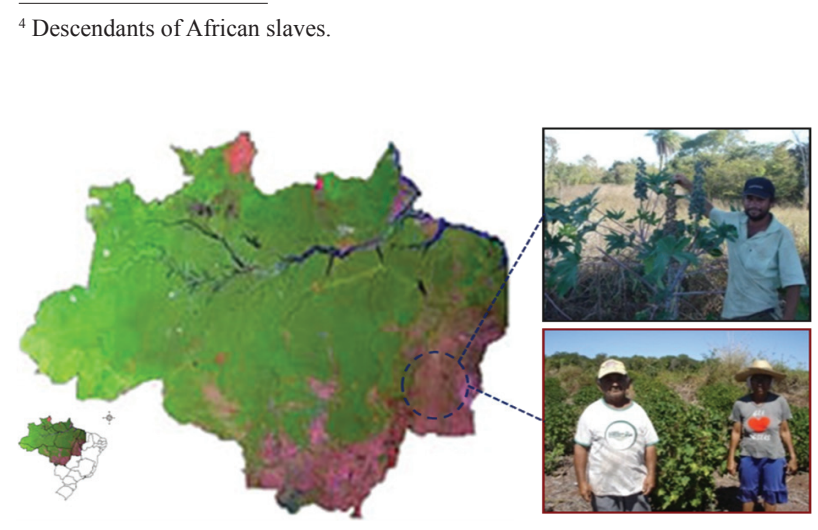

Figure 1. Research area within the Brazilian Legal Amazon region. 
This region is characterized by smallholders under contract with one of the biodiesel companies. All smallholders live in rural settlements created by the national government, through the National Agrarian Reform Program;

2. Ricinus communis sub-study region: comprised by an area from the city of Porto Nacional up to the city of Formoso do Araguaia, in the southwest of the State. This region is characterized by smallholders under contract with the other biodiesel company. All smallholders live in rural settlements created by the national government, through the National Agrarian Reform Program.

The foundation for the database was formed through a comprehensive survey, which was carried out between April and September 2008, in two substudy regions, within the Tocantins State. Specific questionnaires $^{5}$ were applied to smallholders, who were randomly selected. The smallholders selection followed statistical procedures and the sample can be considered representative, since it comprises more than $90 \%$ of small-scale oil seed producers, in the region in question, at the time the research was carried out.

Aiming at better understanding the linkages between the farmers' living standard and the oil seed activity adoption and, therefore, checking the effectiveness of the PNPB's 'pro-poor' strategy, the factor analysis was chosen, and a non-linear probit model was used to demonstrate this relationship with more accuracy ${ }^{6}$. The factor analysis was selected because it enables one to construct a multidimensional poverty index, based on the living standard criteria approach, that is used to assess farming systems (Doppler 1993). A major advantage of using a multi-dimensional measure of poverty, instead of a traditional one (poverty line), is that it does not only take account of the material situation of individuals, but it also captures their general living conditions.

In the traditional approach, poverty is often measured by a poverty line, i.e. all individuals whose income does not exceed a certain level of income are stated to be poor (Betti \& Verma 1999, Costa 2002, Deutsch \& Silber 2005). This approach has clear merits, taking not just the relative number of poors, but both their absolute and relative deprivation.

\footnotetext{
${ }^{5}$ The specific questionnaires comprise economic, financial, social, environmental, cultural, and other aspects of the farmers' living standard.

${ }^{6}$ For this purpose, the software STATA was used to support the factor, as well as the econometric analysis.
}

Nevertheless, it fails to capture a number of features, which may be relevant in thoroughly understanding poverty.

The relationship between rural poverty and environment and social issues is analyzed from different points of view and approaches by several scientists. However, some of those approaches do not put into account the diversity of factors that are intrinsic to the rural poverty conditions, resulting in general conclusions (and not specific) about the relationship. However, there are some studies that express the different dynamics of the rural poverty condition, aiming at enlarging the knowledge that this relationship does not follow one single direction, but might be characterized by several aspects, depending upon the context in which it is embedded (Broad 1994, Reardon \& Vosti 1995, Prakash 1997).

In this context, the factor analysis can be considered a suitable approach, for one strong reason: it allows the construction of a multidimensional index, without a sharp division between poor and non-poor populations. In addition, factor analysis is a broad analysis, including a range of indicators for living standards, while also adopting mathematical tools that can represent the complex character and nuances of the multi-dimensional phenomenon.

\section{The factor analysis ${ }^{7}$}

Factor analysis is an interdependence technique, whose primary purpose is to define the underlying structure among the variables in the analysis, and thus provide the tools to assess the structure of interrelationships (correlations) among a large number of variables, by defining sets of variables that are highly interrelated, known as factors. Therefore, the general aim of factor analysis is to find a way to summarize (condense) the information contained in a number of original variables into a smaller set of new composite dimensions or factors with a minimum loss of information. The factor analysis is then an indicator reduction procedure and a statistical tool used to identify a small number of factors, which reflects complex relationships between these set of variables.

Thus, in the factor analysis, factors are

${ }^{7}$ This section is based on Kim \& Mueller (1978), Jaccard (1997), and Hair et al. (2006). 
estimated as linear combinations between the variables and follow the model described in the equation

$$
F_{j}=\sum_{i=1}^{p} w_{i j} x_{i}=w_{1 j} x_{1}+w_{2 j} x_{2}+\ldots+w_{p_{j}} x_{p}
$$

where $w_{i j}$ represents the factor coefficients, $x_{i}$ are the observed variables, and $p$ is the number of variables, and, therefore, the factor analysis is based on the correlation between the variables. Then, the first step is to check the correlation degree between these variables, which cannot be too small, since it turns the factor analysis non-feasible (if the correlations are too small, probably there is no dimensional structure in the data). For this purpose, there are some specific tests to verify the model adequacy, such as the Bartlett test and the Kaiser-Meyer-Olkin test $(\mathrm{KMO})^{8}$. After the adequacy verification, the establishment of the number and factor extraction is done. In the present study, the component analysis or the principal component analysis (PCA) is used.

The next step is to interpret the factors. When the interpretation is not possible, due to lack of a logical structure, the factors rotation is done. This procedure rearranges the factors matrix, without modifying the total explained variance, aiming at finding a simple and understandable structure. Then, the calculation of factors is carried out. It is important to state that the new variables (i.e. the factors) do not present any lack of information embedded in the original variables. Thus, the calculation is done, as demonstrated in the equation

$$
F_{j k}=\sum_{i=1}^{p} w_{i j} x_{i k}=w_{1 j} x_{1 k}+w_{2 j} x_{2 k}+\ldots+w_{p j} x_{p k}
$$

where $x_{i k}$ is the standardized value of the variable $i$ to the observation $k$, and $w_{i j}$ is the factor coefficient associated to the variable $i$ and factor $j$. One should expect that as poverty is a multidimensional phenomenon, the factors, which are a linear combination of the variables, might reflect different expressions of poverty. Aiming at assessing the dimensions expressed by the factors, a linearization of the scores is done, since the scores are calculated based on standardized variables, and thus might take negative values, which can hinder the factors

$$
{ }^{8} \mathrm{KMO}=\frac{\sum \sum r_{i j}^{2}}{\sum \sum r_{i j}^{2}+\sum \sum a_{i j}^{2}}
$$

where $r_{i j}$ is the coefficient of simple correlation between the variables $x_{i}$ and $x_{i}$, and $a$ is the partial correlation between the variables $x_{i}$ and $x_{i}$. If KMO value is close to one, factor analysis should be applied. assessment. The linearization is expressed by the equation:

$$
f_{i j}=\frac{f-f_{\min }}{f_{\max }-f_{\min }}
$$

where $f_{i j}$ is the linear factor score, and $f_{\min }$ and $f_{\max }$ are, respectively, the minimum and the maximum observed values to the factor scores associated to the indicators, guaranteeing, therefore, that all factor scores lie in the range $[0,1]$.

\section{Variables definition}

Several approaches have been adopted in the field of poverty research, in different regions and contexts, and comprise both quantitative and qualitative aspects. The poverty condition has been defined broadly as a phenomenon of multiple dimensions with economic, cultural, and social aspects, and it is characterized by: a) insufficient income; b) limited access to basic needs; and c) social exclusion and discrimination, due to ethnic or gender origin (Echeverria 2000). The measurement of poverty through indicators that have only one dimension, such as income, can lead to discrepancies in the interpretation of a broader phenomenon.

Therefore, to obtain more accurate analyses of the linkages between farmers' living standard (degree of poverty) and oil seed activity adoption, social, as well as economic indicators, were taken into account. Therefore, variables related to economic and social aspects of households were selected to better demonstrate the multi-dimensional situation of rural poverty, in both sub-study regions in question. The variables selected are shown in Table 1 .

To check whether the proposed model was adequate, a correlation matrix analysis among the twelve indicators was done. The results point towards a low correlation, on average, despite the fact that most of them are significant. In this context, aiming at testing the model adequacy with more accuracy, the Kaiser-Meyer-Olkin (KMO) was applied and shows the figure of 0.64 (low to medium adequacy), which can be explained, at least in part, by the fact that some of the indicators are dichotomous and polytomous, and thus the correlations are not so robust, when compared to continuous variables (Mattos \& Waquil 2005). In addition, the Bartlett's Test of Sphericity was also applied and shows a result of $144.78(p<0.00)$. Therefore, the results suggest that the model can be considered adequate 
Table 1. Living standard indicators.

\begin{tabular}{|c|c|}
\hline Indicator & Description \\
\hline $\begin{array}{l}\text { Family income per } \\
\text { capita }\end{array}$ & $\begin{array}{l}\text { Quantitative variable by nature. The lower anchor is the value of } \mathrm{R} \$ 2,400.00 \text { (Brazilian Reais)* per year, } \\
\text { which is half of the minimum salary established by the national government at the moment the research } \\
\text { was carried out. A person below this value can be considered poor (Yuri 2009). On the other hand, the upper } \\
\text { score is established by multiplying the lower score by two or R } \$ 4,800.00 \text { per year, i.e. the minimum salary } \\
\text { established by law and which reflects that above this value a person cannot be considered poor. }\end{array}$ \\
\hline $\begin{array}{l}\text { Ownership of } \\
\text { durable goods }\end{array}$ & $\begin{array}{l}\text { Ordinal variable. It ranges from } 1 \text { to } 5 \text {, where } 5 \text { means that the family owns all the five goods in question - } \\
\text { television, refrigerator, telephone, gas stove, and a small washing machine - and } 1 \text { when the family owns } \\
\text { just one of these items. }\end{array}$ \\
\hline Means of transport & $\begin{array}{l}\text { Ordinal variable. It ranges from } 1 \text { to } 5 \text {, where } 5 \text { reflects that the family has the car as its main mean of } \\
\text { transportation; } 4 \text { when this mean of transportation is the motorcycle; } 3 \text { when the bicycle is the main one; } \\
2 \text { when the family does not possess any kind of transportation, but can afford a bus ticket; and } 1 \text { when the } \\
\text { family does not possess any means of transportation and cannot afford a bus ticket. }\end{array}$ \\
\hline Toilet facilities & $\begin{array}{l}\text { Dichotomous variable by nature. It receives a value of } 1 \text {, when the family possesses toilet facilities, i.e. toilet } \\
\text { linked to sewer, and } 0 \text {, when the family does not possess it (i.e. latrine or other). }\end{array}$ \\
\hline $\begin{array}{l}\text { Water piped into } \\
\text { dwelling }\end{array}$ & $\begin{array}{l}\text { Dichotomous variable by nature. Its indicator follows that for the toilet facilities, i.e. when the family possess } \\
\text { a system to pipe water into the dwelling, then the family is considered non-poor (1), and if the family does } \\
\text { not possess it, the family is considered poor }(0) \text {. }\end{array}$ \\
\hline $\begin{array}{l}\text { Head educational } \\
\text { level }\end{array}$ & $\begin{array}{l}\text { Ordinal variable. It ranges from } 1 \text { to } 5 \text {, where } 5 \text { reflects that the household head has at least completed the } \\
\text { secondary school; } 4 \text { when the household head started and did not complete the secondary school; } 3 \text { when } \\
\text { the household head completed the primary school; } 2 \text { when the head started and did not complete the primary } \\
\text { school; and } 1 \text { when the household head is illiterate. }\end{array}$ \\
\hline Social capital & $\begin{array}{l}\text { Ordinal variable. It ranges from } 1 \text { to } 3 \text {, where } 3 \text { represents those families who have strong relations with } \\
\text { the rural settlement association, as well as with the rural trade union; } 2 \text { when the families have strong } \\
\text { relationships with only one of them; and } 1 \text { when the families do not have any kind of relationship with the } \\
\text { institutions aforementioned. }\end{array}$ \\
\hline Crowding factor & $\begin{array}{l}\text { Reflects the number of persons who share the same room in a house. The variable is continuous by nature and } \\
\text { has been computed as the ratio between the total number of rooms and an equivalence coefficient determined } \\
\text { on the basis of the OECD scale. Accordingly, the following scores have been used: } 1 \text { for the first adult; } 0.7 \\
\text { for any other adult ( } 18 \text { and over); and } 0.5 \text { for children (under } 18 \text { ). }\end{array}$ \\
\hline Health condition & $\begin{array}{l}\text { Ordinal. Values range from } 1 \text { to } 3 \text {, where } 3 \text { reflects that the family is not sick (good health conditions); } 2 \\
\text { when the family is sick, but that is not considered severe (regular health conditions); and } 1 \text { when it is severely } \\
\text { sick (bad health conditions). }\end{array}$ \\
\hline Food security & $\begin{array}{l}\text { Ordinal variable. It ranges from } 1 \text { to } 3 \text {, where } 3 \text { demonstrates that the family has never faced food shortage } \\
\text { during the year; } 2 \text { when the family has faced food shortages, but not regularly, i.e. a deficit on food consumption } \\
\text { during the year; and } 1 \text { when the family regularly copes with food shortage. }\end{array}$ \\
\hline $\begin{array}{l}\text { Resource } \\
\text { dependence }\end{array}$ & $\begin{array}{l}\text { Dichotomous variable by nature and, thus, families have been split into poor (0), when they rely on the } \\
\text { municipality and/or on the association's machinery to run the farm activities; and non-poor families (1), } \\
\text { when they do not depend on the municipality and/or on the association's machinery to run farm activities. }\end{array}$ \\
\hline $\begin{array}{l}\text { Drinking water } \\
\text { shortage }\end{array}$ & $\begin{array}{l}\text { Dichotomous by nature. Families who face a shortage of drinking water during the year receive the value } \\
\text { "0", and are considered poor. Families who do not face this problem during the year are considered non- } \\
\text { poor and receive the value " } 1 \text { ". }\end{array}$ \\
\hline
\end{tabular}

* At the time this study was conducted, one Brazilian Real (R\$) was equivalent to 0.5 American Dollars (US\$).

and satisfactory, regarding the exploratory nature of the present study.

After the correlation matrix and the result from the $\mathrm{KMO}$, as well as the Bartlett's test, the factor analysis was adopted and factor extractions were done. The initial number of factors should follow some considerations, such as application of the latent root criterion of retaining factors with Eigen values greater than 1.0. In addition, the Scree test, derived by plotting the latent roots against the number of factors in order of extraction, was also used to evaluate the cutoff point.
The indicators follow an increase degree of living standard, i.e. high values reflect better living standard conditions. Based on this, the factor analysis was applied to reduce the number of variables towards a small number of factors which, for their turn, reflect the original variables. The point at which the curve first begins to straighten out is considered to indicate the maximum number of factors to be extracted. Therefore, four different factors could be identified, which are responsible for roughly 55\% of the total data variance. In addition, the Scree 
plot, based on Eigen values, was estimated and also reflected four different factors.

\section{RESULTS AND DISCUSSION}

After the factors extraction, the orthogonal rotation based on the Varimax method was applied, aiming at turning the factors into more understandable results. The Varimax method aims to simplify the columns of the matrix factor. Thus, the maximum possible simplification is reached if there are only 1 and 0 values in the columns, i.e. the method maximizes the sum of variances of matrix factor's required loadings, aiming at obtaining an orthogonal rotation of factors. The rotated matrix is presented in Table 2.

Factor loadings from \pm 0.30 to \pm 0.40 usually are considered adequate to meet the minimal level for structure interpretation. However, as the present study's sample lays around 100 units (smallholders), the range considered adequate was above \pm 0.45 . To interpret the factors, it is necessary to pay attention to the higher figures presented in Table 2, since higher figures represent higher weights on factor composition. In this context, the factor 1 seems to reflect capital security, once it is represented by family income per capita, ownership of durable goods, means of transport, and presence of toilet linked to sewer, as well as presence of water piped into dwelling.

The factor 2 seems to reflect a dependence on external resources, and comprises the indicators resource dependence, crowding factor, and head

Table 2. Rotated component matrix.

\begin{tabular}{lcccc}
\hline \multirow{2}{*}{\multicolumn{1}{c}{ Indicators }} & \multicolumn{4}{c}{ Component } \\
\cline { 2 - 5 } & \multicolumn{1}{c}{2} & \multicolumn{1}{c}{3} & \multicolumn{1}{c}{4} \\
\hline Family income per capita & $\mathbf{. 7 5 8}$ & .091 & .096 & .134 \\
Durable goods & $\mathbf{. 4 9 7}$ & -.447 & .160 & -.351 \\
Means of transport & $\mathbf{. 5 2 0}$ & .100 & .214 & .012 \\
Toilet facilities & $\mathbf{. 6 6 8}$ & -.059 & -.237 & -.145 \\
Water piped into dwelling & $\mathbf{. 6 8 9}$ & -.144 & .048 & -.248 \\
Head educational level & -.276 & $\mathbf{. 4 9 0}$ & -.467 & .120 \\
Social capital & .060 & .041 & .268 & $\mathbf{. 6 8 7}$ \\
Crowding factor & -.049 & $\mathbf{- . 5 7 6}$ & -.197 & .438 \\
Health situation & .188 & -.062 & .179 &.- .563 \\
Food security & .129 & .013 & $\mathbf{. 6 3 9}$ & -.037 \\
Resource dependence & .102 & $\mathbf{. 8 0 1}$ & .128 & .146 \\
Drinking water shortage & -.087 & .135 & $\mathbf{. 7 2 2}$ & .061 \\
\hline
\end{tabular}

Notes: Bold values reflect factor loading above 0.45 . Extraction Method: Principal Component Analysis. Rotation Method: Varimax with Kaiser Normalization. educational level. The factor 3 reflects natural resources insecurity, since it is linked to the variables food security and drinking water shortage. Both variables have positive signs and move together in the same direction, while the head educational level appears as a cross-loading factor, i.e. when a variable is found to have more than one significant loading. As this variable has the higher weight in factor 2, its value was not considered in factor 3 . And last but not least, the factor 4 seems to reflect social security. Here the factor is linked to the variable social capital, as well as to health condition. Both variables are negatively correlated.

An option for creating a smaller set of variables to replace the original one is the computation of factor scores, which are composite measures of each factor computed for each subject. So, the factor scores are estimated and then a process of linearization is done, aiming at avoiding negative factor scores values, and thus guaranteeing that all scores lie in the range $[0,1]$.

After the linearization, a non-linear probit model was applied to estimate the relationship between the living standard factors and the adoption of oil seeds activity by small-scale farmers, in both sub-study regions (Greene 2008, Hill et al. 2008). In this context, two regressions were estimated: one for the Ricinus communis region, and one for the Jatropha curcas region. The analysis per sub-study region is necessary, since the smallholders are located in different areas, produce different oil seeds, and have contracts with different biodiesel companies ${ }^{10}$. Therefore, the weights for each indicator of deprivation were calculated per sub-study region, taking into account the peculiarities and nuances, and, therefore, the relative importance of each indicator of deprivation in each region.

The probit model formulated was:

$$
\begin{aligned}
Y_{j}=\alpha & +\beta_{0}{\text { factor } 1_{j}}_{j}+\beta_{1} \text { factor }_{j}+\beta_{2} \text { factor }_{j}+ \\
& +\beta_{3} \text { factor }_{j}+\mu_{j}(j=1, \ldots, \mathrm{n}),
\end{aligned}
$$

where the dependent variable $Y$ refers to the adoption of oil seeds $(Y=1)$ or otherwise $(Y=0), \alpha$ and $\beta$ are the parameters of the equation, $\mu$ is the stochastic term, and the factors ( 1 to 4 ) are the explanatory variables. Hence, when the signs of the estimated coefficients from the models are positive, the relationship between living standard and adoption of

\footnotetext{
${ }^{9}$ Other options are: i) selecting surrogates; and ii) creating summated scales.

${ }^{10}$ A one-year contract, for the Ricinus communis producers, and a ten-year contract, for the Jatropha curcas producers.
} 
oil seed activity is direct, i.e. the probability of poor families adopting oil seed activity is smaller than that of their non-poor counterparts, and, therefore, the 'pro-poor' strategy is not being effective. By contrast, when the coefficient is negative, the relation is the inverse, i.e. poor families have a higher probability of adopting oil seed activity and thus the social inclusion advocated by the PNPB is taking place. Based on this, the results of the probit model can be seen in Table 3.

According to the results of the probit model, one can observe that all coefficients are significant, either at the $1 \%, 5 \%$, or $10 \%$ level. Also the likelihood ratio Chi-Square is significant at the $1 \%$ and $5 \%$ levels. Regarding the signs of the coefficients, positive signs reflect a direct relationship between better living standards and the adoption of oil seed activity. In this context, in the Ricinus communis region, for instance, the sign of the coefficients are negative (except for factor 4 ), i.e. a poor family has, on average, a higher probability of adopting the oil seed activity than a non-poor family. This outcome shows that, in this region, the social inclusion advocated by the PNPB is occurring, in other words, poor families are being included in the Brazilian biodiesel chain.

However, when one looks to the other region, the Jatropha curcas region, the signs of the coefficients are positive, showing that the better the living standards of families, on average, the higher the probability to adopt the oil seed activity, when compared to those who are considered poor. Therefore, the results suggest that social inclusion is not occurring, once the poor families are not taking part in the biodiesel production process, and thus, in this case, the effectiveness of the PNPB's 'pro-poor' strategy is doubtful.

The changes in the predicted probability for the factors were also estimated and show that, for the Ricinus communis producers, a movement from 0 (worse living standard) to 1 (better living standard) changes the probability of factor 1 to $49 \%, 60 \%$ for factor 2 , and $41 \%$ for factor 3 , i.e. a movement towards a better living standard condition decreases the probability of adoption of oil seed activity in these percentages (except for factor 4, whose coefficient is positive). However, for the Jatropha curcas producers, a movement from 0 (worse living standard) to 1 (better living standard) changes the probability of factor 1 to $71 \%, 76 \%$ for factor $2,53 \%$ for factor 3 , and $81 \%$ for factor 4 , i.e. a movement towards better living standard conditions increases, on average, the probability of adopting the oil seed activity in these percentages.

One possible explanation for the results from the probit model relies on the short horizon outlook and risk aversion embedded in the poverty condition. The bad living standards, for example, the weak access to goods and services, and, therefore, the high vulnerability to disasters (natural and man-made), make the poor uncertain and insecure about the future. In addition, the risk aversion began from the limited assets available and the low educational level of family members. This put poor rural families into a precarious economic balance, where families prefer short-term activities rather than medium to long-term projects (Reardon \& Vosti 1995).

This seems to be what happens to the Ricinus communis oil seed production. Ricinus is an annual crop and its production is based on a one-year contract with the biodiesel company, which allows farmers to quit the activity in the following year, in case of bad harvest and low productivity of the feedstock. However, this is not the case of the Jatropha curcas oil seed. Jatropha is a perennial crop and its activity is based on a ten-year contract with the biodiesel company. The oil seed becomes economically profitable after the fourth year, and, thus, requires a

Table 3. Regression results for the non-linear probit model.

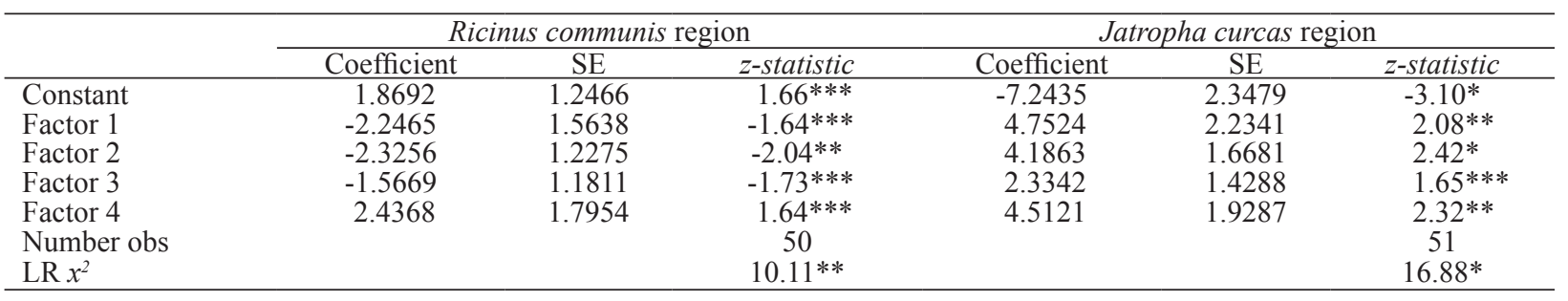

Notes: SE $=$ standard error; $*$ Significance level of $0.01 ; * *$ Significance level of $0.05, * * *$ Significance level of 0.10. 
diversified portfolio from the farmers' perspective. Therefore, the long-term horizon, concerning the Jatropha production, seems to be more attractive to the farmers in the mentioned region, which present, on average, a broad spectrum of capital assets. It is important to say that there is no different treatment by local and national governments, considering the two sub-study regions, i.e. the basic infrastructure conditions, such as roads and energy, are similar in both regions.

In summary, apart from the fact that the Brazilian biodiesel use and production program (PNPB) possesses the laudable objectives of promoting social inclusion and regional development, the results presented hitherto demonstrate and suggest that a lack in specific policy mechanisms has resulted in the non-fulfillment of one of its main targets: inclusion of marginalized people in the biodiesel chain. Based on this, it is imperative to say that the involvement of local agents seems to be a sine qua non condition to overcome the shortcomings in policy mechanisms, by aiming to minimize gaps in the national biodiesel policy and, therefore, reach the social inclusion and the sustainable development advocated by the PNPB.

\section{FINAL REMARKS}

The study presents an example of application of a multi-dimensional measurement of poverty, by using factor analysis. The empirical results obtained for the Tocantins State, located in northern Brazil, show that the use of several indicators not only helps to draw a more comprehensive and complete picture of living standard, but also gives an image of rural poverty that is closer to what is perceived by just observing reality. Nevertheless, for many reasons, the results depend strongly on the choice of indicators for this kind of analysis, so it would be worth selecting and defining an appropriate set of indicators to include the data, covering all the relevant areas, for a broader analysis of living conditions.

The debate about bioenergy and social inclusion is currently considered a hot topic and the study reveals the dynamicity of the linkages between two multi-dimensional phenomena. The ambiguity of this relationship, highlighted by the results of the factor analysis and the probit model, illustrates that the Brazilian biodiesel use and production program (PNPB), target of social inclusion, cannot yet be seen as successful. In one sub-study region, for instance, it is clear that the poor families are being included in the Brazilian biodiesel chain, but, in the other sub-study region, the poor families continue to be marginalized, without access to this new economic alternative.

The regional development of one of the poorest regions of the country (northern Brazil) needs special attention. The reality of family farming in northern Brazil follows the diversity of the country, and, thus, it is completely different from other regions. These differences, along with the natural endemic characteristics of the region, make the development of the Tocantins State a challenge, especially when it includes the biodiesel and oilseed production by family farmers. Only a more critical look at regional differences will allow the PNPB to meet its goals of social inclusion and income generation in the field, in the context of sustainable development. Based on this, we strongly suggest that other studies be carried out, aiming at better understanding the reasons behind the inclusion and non-inclusion of farmers in the biodiesel chain.

This study is unprecedented in the northern region of Brazil and its results are extremely important in helping to obtain an appropriate method for regional and national governments to subsidize clean energy production, in order to bring the real benefits provided by the program to those who should actually be assisted in achieving social inclusion: the family farmers. Although the present research focuses on the Tocantins State, small-scale oil seed production can now be better gauged in other parts of the Brazilian Legal Amazon, because our study highlights one of the most discussed topics in the bioenergy debate: oil seed production and its linkages with farmers' living standard. As the present study focuses only at family level, in a specific region, we also suggest that further studies should be focused on the biodiesel production, on both regional and national levels, in order to attain a broader idea of the biodiesel production in Brazil.

\section{REFERENCES}

ABRAMOWAY, R.; MAGALHÃES, R. The access of family farmers to biodiesel markets: partnerships between big companies and social movements. 2007. Available at: $<$ http://www.abramovay.pro.br/artigos cientificos/2007/Biodiesel_AIEA2_English.pdf $>$. Acess on: 15 Aug. 2010. 
AGÊNCIA NACIONAL DO PETRÓLEO, GÁS NATURAL E BIOCOMBUSTÍVEIS (ANP). Biodiesel statistics. 2010. Available at: <http://www.anp.gov.br/>. Acess on: 10 Mar. 2010.

BETTI, G.; VERMA, V. K. Measuring the degree of poverty in a dynamic and comparative context: a multidimensional approach using fuzzy set theory. In: ISLAMIC COUNTRIES CONFERENCE ON STATISTICAL SCIENCES, 6., 1999, Lahore. Proceedings... Lahore: Punjab University, 1999. p. 289-301.

BRASIL. Governo Federal. Programa nacional de produção e uso de biodiesel (PNPB). 2005. Available at: $<$ http://www.biodiesel.gov.br/programa.html $>$. Acess on: 23 Nov. 2009.

$\mathrm{BROAD}, \mathrm{R}$. The poor and the environment: friends or foes? World Development, Quebec, v. 22, n. 6, p. 811-22, 1994.

COSTA, M. A multidimensional approach of the measurement of poverty: IRISS working paper series n. 2002-05. 2002. Available at: <http://iriss.ceps.lu/ documents/irisswp28.pdf $>$. Acess on: 26 Oct. 2009.

DEUTSCH, J.; SILBER, J. Measuring multidimensional poverty: an empirical comparison of various approaches. Review of Income and Wealth, Malden, v. 51, n. 1, p. 145174, 2005.

DOPPLER, W. Contribution of the farming systems approach to regional food security and rural infrastructure. In: THIMM, H. U. et al. (Eds.). Regional food security and rural infrastructure. Münster: Verlag, 1993.

DUBOIS, O. How good enough biofuel governance can help rural livelihoods: making sure that biofuel development works for small farmers and communities. Rome: FAO, 2008.

ECHEVERRIA, R. G. Opciones para reducir la pobreza rural en América Latina y el Caribe. Revista de la CEPAL, Santiago, n. 70, p. 147-160, 2000.

FOOD AND AGRICULTURE ORGANIZATION OF THE UNITED NATIONS (FAO). Bioenergy, food security and sustainability: towards an international framework. 2008a. Available at: <http://www.fao.org/fileadmin/ user_upload/foodclimate/HLCdocs/HLC08-inf-3-E.pdf $>$. Acess on: 26 Oct. 2009.

FOOD AND AGRICULTURE ORGANIZATION OF THE UNITED NATIONS (FAO). Climate change, bioenergy and food security: civil society and private sector perspectives. 2008b. Available at: $<$ http://www.fao. org/fileadmin/user_upload/foodclimate/HLCdocs/HLC08inf-6-E.pdf>. Acess on: 26 Oct. 2009.

FOOD AND AGRICULTURE ORGANIZATION OF THE UNITED NATIONS (FAO). Climate change, bioenergy and food security: options for decision makers identified by expert meetings. 2008c. Available at: $<$ http://www.fao. org/fileadmin/user_upload/foodclimate/HLCdocs/HLC08inf-5-E.pdf>. Acess on: 26 Oct. 2009.
GARCEZ, C. A. G.; VIANNA, J. N. S. Brazilian biodiesel policy: social and environmental considerations. Energy, Aalborg, v. 34, n. 5, p. 645-654, 2009.

GREENE, W. H. Econometric analysis. 6. ed. New Jersey: Prentice Hall, 2008.

HAIR, J. F. et al. Multivariate data analysis. 6. ed. New Jersey: Prentice Hall, 2006.

HILL, R. C.; GRIFFITHS, W. E.; LIM, G. C. Principles of econometrics. 3. ed. Danvers: John Wiley and Sons, 2008.

JACCARD, J. Interaction effects in factorial analysis of variance: quantitative applications in the social sciences. Thousand Oaks: Sage, 1997.

KIM, J. O.; MUELLER, C. Factor analysis: statistical methods and practical issues. Newbury Park: Sage, 1978.

MATTOS, J. E.; WAQUIL, P. D. Pobreza rural no Rio Grande do Sul: comparando abordagens. 2005. Available at: <http://www.fee.tche.br/3eeg/Artigos/m03t04.pdf $>$. Acess on: 12 Oct. 2009.

NASS, L.; PEREIRA, P.; ELLIS, D. Biofuels in Brazil: an overview. Crop Science, Madison, v. 47, n. 6, p. 22282237, 2007.

PIERSON, J. Tackling social exclusion: social work skills series. New York: Routledge, 2002.

PRAKASH, S. Poverty and environment linkages in mountains and uplands: reflections on the 'poverty trap' thesis. 1997. Available at: <http://www.prem-online.org/ archive/17/doc/creed12e.pdf $>$. Acess on: 13 Sep. 2009.

RAJAGOPAL, D.; ZILBERMAN, D. Review of environmental, economic and policy aspects of biofuels. 2007. Available at: <http://www-wds.worldbank.org/ external/default/WDSContentServer/IW3P/IB/2007/09/0 4/000158349 20070904162607/Rendered/PDF/wps4341. pdf $>$. Acess on: 26 Oct. 2009.

REARDON, T.; VOSTI, S. Links between rural poverty and the environment in developing countries: asset categories and investment poverty. World Development, Quebec, v. 23, n. 9, p. 1495-1506, 1995.

SILVER, H.; MILLER, M. Social exclusion: the European approach to social disadvantage. 2002. Available at: $<$ http://www.ag.ohio-state.edu/ hcrd/people/staff/ Social\%20Exclusion\%20The\%20European\%20approach. pdf $>$. Acess on: 15 Mar. 2010.

UN ENERGY. Sustainable bioenergy: a framework for decision makers. 2007. Available at: <http://www.fao. org/docrep/010/a1094e/a1094e00.htm>. Acess on: 26 Oct. 2009.

YURI, D. Programa das Nações Unidas para o desenvolvimento (PNUD). 2009. Available at: $<$ http:// www.pnud.org.br/gerapdf.php?id01=2802>. Acess on: 26 Oct. 2009. 